Kohl: a Journal for Body and Gender Research

Vol. 4, No. 1 (Summer 2018)

\title{
Parliamentary Elections, Civil Society, and Barriers to Political Change
}

Joumana Talhouk 
Weeks have passed since Lebanese citizens cast their ballots in the first parliamentary election in 9 years. The event did not make a major impact on people's lives; if not for the remnants of posters plastered all over highway billboards and city walls, one can almost forget that elections occurred at all. The campaign hype lasted for months prior to election day, especially among the independent opposition groups, who viewed the new proportional electoral system as a golden opportunity for breaking through the corrupt establishment and creating "real" change in the country. The results were disappointing to those who believed that May 6, 2018 was an entry point for overthrowing the political system. However, for many, the elections never represented a grand opportunity for change or the ultimate gateway for political salvation, particularly in the Lebanese context.

\section{Changes to the Lebanese Electoral Law}

In previous elections cycles, Lebanon adopted a majoritarian system, in which candidates ran in open lists, meaning voters were free to cross out names from one list and add candidates from another. The law divided the country into 26 electoral districts that would elect a total of 128 members of parliament. The 1989 Taif agreement introduced parity between Christians and Muslims in parliament to the Lebanese constitution, and the number of seats reserved for each confession within the two religions also follows a strict quota system.

The new electoral law, ratified in June 2017, reduces the 26 districts to 15; still considerably small, the districts limit fair representation. Under this new system, candidates could only run within closed lists, meaning voters could not mix and match between candidates. In addition to choosing a list, voters could cast a preferential vote to only one candidate running in their chosen list.

Allocating seats under this law is a complicated process. The first step is counting whether lists have passed the required threshold. The second step is determining the winning candidates from each winning list. This depends on the candidate's sect in addition to their percentage of all preferential votes within the district, since a sectarian quota needs to be fulfilled. The consequence of this quota, applied within a proportional system, is creating a majoritarian competition between candidates of the same confession; the result was that candidates belonging to sects that were not already filled by more dominant lists could beat candidates who secured more preferential votes within their list. ${ }^{1}$

The changes to Lebanon's electoral system and their implications are very well explained by Zeina Ammar (2018), who argues that "while the new law allows for a greater possibility that minor coalitions will gain representation, the shift in that direction is marginal."

\footnotetext{
${ }^{1}$ In Zahle, where 94,082 votes were cast, a candidate won the Armenian Orthodox seat with only 77 votes because all other sectarian seats were already filled by other lists.
} 
While new independent electoral campaigns under the umbrella of "civil society" 2 were hoping to break through the "system" in this election, traditional ruling political parties were successfully re-elected with overwhelming majority.

The "civil society" electoral campaigns generally ran on the basis that winning seats in parliament would be a big blow to the system, and having a representative there would enable civil society to act as watchdogs to legislative and executive bodies, to propose draft laws, and to gain more visibility in the political arena as a voice of opposition. In their view, after accumulating experience through protests and the 2016 municipal elections, it was time to unify efforts across the board and take the battle to the national scale; a good, clean, and effective performance in parliament would give people confidence in the opposition and allow for bigger representation in the next electoral cycle, until one day the opposition would become a majority.

Thus, "Kollouna Watani" was formed, a wide coalition of various civil society campaigns and newly formed parties, including "Libaladi," an offshoot from Beirut Madinati, ${ }^{3}$ "Lihaqqi," a grassroots campaign in ChoufAley, "Tol3et Ri7etkon" (You Stink), the campaign that began with the 2015 garbage crisis, "Sabaa," a newly emerged party founded by Jad Dagher ${ }^{4}$ with a program supporting the privatization of the majority of services, "Mouwatinoun wa Mouwatinat fi Dawla" (Citizens within a State), a party led by ex-minister Charbel Nahas, ${ }^{5}$ and "Sah," a group of ex-members of the Free Patriotic Movement led by Ziad Abs, ${ }^{6}$

2 The term "civil society" in Lebanon has become quite contested in light of the parliamentary elections. One of its designated meanings is that civil society in Lebanon encompasses those who did not partake in the civil war (19751990) and organized in the post-war period through non-governmental organizations as opposed to joining sectarian political parties. In some definitions, "civil" in civil society is a contrast to "military" and so includes political parties as well as NGOs, while other definitions consider civil society as non-state actors who serve as watchdogs to the state. At the backdrop of the election, "civil society" as a term had evolved from what was called the "civil movement" in 2015 against the garbage crisis. One of the problems with using this vague and shifting term during elections was that it allowed candidates and campaigns who were never part of the movements that came to be known as "civil society" to co-opt the label, claiming to represent organizing efforts that had evolved over the years. For example, Sabaa, a neoliberal party founded by businessmen in 2017, was able to claim representation of civil society by adopting a minimalist anti-corruption discourse and spending millions of dollars to be at the forefront.

${ }^{3}$ An urban political group that was initiated as a campaign for the 2016 municipal elections in Beirut. The campaign was seen as a ray of hope across Lebanon, especially for securing $40 \%$ of the votes against a unified list of ruling political parties.

${ }^{4} \mathrm{~A}$ former member of the Kataeb party, Jad Dagher is known as a wealthy businessman who was allegedly shipping banknotes for the Syrian government in 2014. He founded Sabaa party in 2017 and currently serves as its Secretary General.

${ }^{5}$ Charbel Nahas served as Minister of Labor as part of the Change and Reform bloc. He founded the group Mouwatinoun wa Mouwatinat fi Dawla, which ran for the 2016 municipal elections in Beirut. He is currently the group's Secretary General.

${ }^{6}$ Ziad Abs was a central member of the Free Patriotic Movement (FPM) for years and headed the party's Beirut committee. He played a leading role in forming the memorandum of understanding between the FPM and Hezbollah in 2006. He was expelled from the party after an organizational disagreement with the leadership. He created "Sah," a group of ex-Aounists, which joined the "Kollouna Watani" coalition. This caused backlash among activists because 
among others. The diverse groups in this coalition agreed on basic political guidelines and adopted a common political paper, but it was clear that what joined them was the belief that the wider the coalition, the bigger the chances of "breaking through the system," or winning a seat in parliament.

Despite this broad alliance, "Kollouna Watani" lists across 9 districts secured just over $2 \%$ of the total number of votes in Lebanon, while all "civil society" lists secured less than $5 \%$. The only successful "civil society" candidate was Paula Yacoubian, former Future TV reporter and Sabaa party's candidate in Beirut 17. Many today do not consider this breakthrough a success, partially because of Sabaa's program and politics, and partially because of Yacoubian's profile and proximity to ruling parties. The traditional parties governing the country since the end of the Lebanese civil war re-established their dominance over the national political landscape through this election. All in all, the supposed opportunity for change was missed.

In their attempt to break through the system, "civil society" ended up playing by the establishment's rules. There were a number of alarming practices that deserve to be highlighted and discussed. While the political necessity of building coalitions is understandable, implying a joint vision normalizes certain campaigns and groups that hold views fundamentally different and sometimes contradictory to those of activists, such as privatization and anti-refugee policies, therefore effectively harming our movements rather than supporting them. Efforts to unify all opposition groups and present a discourse that appeals to a vast number of voters with the intention of securing representation in parliament resulted in acts of policing and exclusion.

\section{Elections as Inherently Exclusionary}

Parliamentary elections in Lebanon is a political act inaccessible to many, so how can it be the tool for political change? Submitting one's candidacy alone costs $\$ 5000$, while running a visible campaign costs no less than a few hundred thousand dollars. Even voting is a privilege considering the numerous obstacles in the electoral process and the fact that non-citizens constitute almost one-third of Lebanon's population.

In Lebanon, citizens are classified in registries by their hometown, their sect, their families, and their sex. This classification is followed in the elections, where voting booths are distributed according to these categories. Nadine Moawad (2018) gives a step-by-step breakdown of how Lebanese citizens are classified by the state and thus registered to vote. What this classification entails is that women are secondclass citizens, as they are listed under the families of either their fathers or their husbands and can never become independent from a man in the Lebanese registries. This is particularly alienating for married women who neither live in their hometowns nor in their husbands', meaning that they have to travel to their husband's hometown to cast a vote.

of his attacks on Electricite Du Liban strikers in 2012, his anti-refugee position, his sectarian discourse, and his questionable interests in the oil and gas sector.

${ }^{7}$ A predominantly Christian electoral district with 8 seats, all allocated for Christians. 
Voting in one's hometown rather than one's residency place also creates class barriers, making it harder for people without means of transportation to practice their right to vote. This plays in favor of established political parties that customarily provide transportation for their voters. Some voting centers in Lebanon, specifically in small towns and villages, have only a few hundred registered voters, making it easier for parties to track voters' choices and verify whether their alleged supporters - or those whose votes were bought - fulfilled their promises. So, if one cannot afford to travel to their hometown to vote, the usual choices are to either vote for the dominant party in their area in exchange for money and/or transportation, or to boycott the elections altogether.

By nature of being the exclusive right of Lebanese citizens, the elections immediately exclude the almost 2 million non-citizens residing in the country. A half million Palestinian refugees, over a million Syrian refugees, and a few hundred thousand migrant workers suffer severe violations of their basic rights and are regularly scapegoated by politicians as responsible for the country's failures. Especially in a country where political stability is contingent upon a balance of power (even if merely perceived) between its various sectarian leaders, the prospect of granting social, economic, and political rights to non-citizens seems impossible. In fact, the presence of Syrian and Palestinian refugees in Lebanon is often utilized in stirring sectarian conflicts, given that the majority of those refugees are Sunni Muslims. So, naturally, for a great number of people in Lebanon, the elections never had the promise of making a positive change.

The state's hostility extends to Lebanese citizens as well. Any bureaucratic process involving direct interaction with the state can be extremely difficult for members of the LGBTQ+ communities, especially trans ${ }^{*}$ persons who have undergone gender-affirming therapies and surgeries. Given that all identification cards and paperwork refer to the person's name and sex assigned at birth, the act of voting can be impossible for someone who no longer resembles the gender associated with the sex assigned to them at birth, being at risk accusations of identity theft or verbal or physical harassment at voting booths.

\section{Independent Campaigns and/or Foregone Allies}

This election was a harsh reminder of the extent to which these communities are marginalized; the system actively suppresses their voices, and "civil society" effectively deemed them irrelevant as non-voters. While trying to seriously compete under an electoral law that includes sectarian quotas and organizes electoral districts across sectarian geographies, independent campaigns adopted a discourse that would neither disturb the core of the system nor challenge its gravest injustices. Regardless of intentions, in avoiding taking clear, unapologetic stances on issues such as secularism, economic policies, class, refugee rights, migrant rights, and LGBTQ+ rights, the vast majority of "civil society" campaigns were effectively complicit in sidelining the most disadvantaged communities in Lebanon.

The fact that many independent campaigns did not carry a discourse that elevated the causes and movements of civil society groups that had been active for years was highlighted during the election period. 
A number of articles and statements pointed to the absence of political clarity and the unassuming nature of independent lists' campaigns. Mist3ideen, a group that positions itself against the Lebanese regime and at odds with the flawed available alternatives, was formed as an initiative to evaluate independent candidates based on a political criteria they described as progressive. The initiative released a comprehensive position on independent campaigns and the unprincipled coalitions that included racist, sectarian, homophobic, transphobic, neoliberal, and corrupt politicians in their lists for electoral gains. The A Project (2018) also published a powerful critique on the supposedly pro-LGBTQ+ agenda of some campaigns and candidates, raising the important point that abolishing article 534 is not nearly enough to be pro-LGBTQ+ rights, stating that "to make the case that queers and trans" folk only care about 534, not being hated, or getting a very light and disgusted (or heavy on and coopting) pat on the back - is belittling. Its condescending. Its offensive. And worse - its just not true."

Such criticisms were met with a range of harsh accusations, such as serving the ruling parties by scrutinizing the alternative in the midst of the election, thereby dividing the ranks of the opposition and decreasing their chances of winning. Instead of accepting feedback from fellow activists, some campaigns and candidates utilized emotional blackmail and policing to push back against criticism. This is what winning a seat in parliament at all costs looked like: claim to represent existing anti-establishment movements, form a purely tactical coalition under the vague umbrella of "civil society" for electoral gain, avoid taking clear stances regarding controversial issues or supporting unpopular opinions, and attack those who criticize your tactics for harming "the cause" of challenging the system.

In an article analyzing the elections results, Lara Bitar (2018) argues that "non-cooperation and the refusal to be complicit in the state's self-preservation attempt is one of the few acts of resistance the working class could engage in without fear of vengeance by the state and its militias." Unfortunately, in collective and individual assessments of the elections, a number of candidates are holding on to these tactics of intimidation, blaming everybody but themselves for their failure. Through Facebook posts, panel discussions, and articles, various campaigners and candidates are attributing their loss to the low voter turnout, the criticism from people who were supposed to be allies in the electoral battle, and the numerous violations in the electoral process. Very few candidates have actually gone through a genuine exercise of self-evaluation, or at least shared it with the public. Instead, the most common assessments describe those who did not come out to vote or voted for ruling parties as working against their own interests, assume that the opposition or "civil society" is one entity even though the very campaigns that ran for elections made decisions without including their supposed allies and constituencies, and blame the electoral process that is known to be flawed without questioning what their participation in that very process meant in terms of legitimizing it or even challenging it until the results came out.

\section{Concluding Thoughts}

The 2018 election was a slap in the face for civil society groups running with hopes of reaching parliament, which ended up representing only $5 \%$ of the 1.82 million who voted. However, it exposed practices and 
issues that had previously been swept under the rug. Conversations about forms of organizing, legitimacy and representation, state and civil society, the importance of taking positions from contentious issues, and how to effectively disrupt the Lebanese political system are happening. While such discussions were previously being held among intellectual circles and behind closed doors, different groups of activists and organizers are now deliberately engaging in them, not only as a mental exercise, but also with the purpose of imagining and working towards inclusive and constructive alternatives.

Despite the systemic flaws and inherent shortcomings of elections as a process, they could still be perceived as a viable strategy and platform for political engagement, albeit not the only one. Elections present an opportunity to openly campaign at a time when people are receptive and paying attention. However, making use of this opportunity requires a clear discourse, ideology, and/or program that are not dialed down for fear of losing votes, and that are definitely inclusive of marginalized communities, both through discourse and in practice. This implies expanding our perspective on elections beyond running and voting, to include critiques of the system, campaigns to boycott, and producing alternative discourses as legitimate and important practices of engagement. 